\title{
More on Mesozoic Membracoidea (Homoptera)
}

\section{Снова о мезозойских мембракоидах (Homoptera)}

\author{
Dmitry E. Shcherbakov \\ Амитрий Е. Щербаков
}

Borissiak Paleontological Institute, Russian Academy of Sciences, Profsoyuznaya St. 123, Moscow, 117997 Russia; dshh@narod.ru Палеонтологический институт им. А.А. Борисяка РАН, Профсоюзная ул. 123, Москва, 117997 Россия.

KEY WORDS: Homoptera, Cicadomorpha, Membracoidea, Hylicellidae, Archijassidae, Karajassinae, fossil, phylogeny, venation, jumping, brochosomes, Mesozoic, Triassic, Jurassic, Cretaceous.

КЛЮЧЕВЫЕ СЛОВА: Homoptera, Cicadomorpha, Membracoidea, Hylicellidae, Archijassidae, Karajassinae, ископаемые, филогения, жилкование, прыжок, брохосомы, мезозой, триас, юра, мел.

ABSTRACT. New monobasic genera from the Middle Jurassic of South Siberia (Kisa fasciata gen. et sp.n., Kubecola guttatus gen. et sp.n., Kemobius lux gen. et sp.n.) and Cicadellium Westwood, 1854 are placed in the subfamily Karajassinae stat.n. Cicadellium psocus Westwood, 1854 (= Cercopidium telesphorus Westwood, 1854, syn.n.) is designated as the type species of the genus Cicadellium (the second species, $C$. dipsas Westwood, 1854 is transferred to Psocoptera). A new monobasic genus from the Upper Jurassic of South Mongolia (Dellashara tega gen. et sp.n.) and four Early Cretaceous genera are assigned to the subfamily Dellasharinae subfam.n. Both subfamilies are included into the family Archijassidae placed in the superfamily Membracoidea. Mesojassus Tillyard, 1916 and Triassojassus Tillyard, 1919 from the Upper Triassic of Australia belong in Archijassinae and represent the earliest records of the superfamily. The sequence of acquisition of membracoid features is outlined. The early evolution of Membracoidea is discussed. Karajassinae probably coated their integuments with brochosomes or related particles produced in the Malpighian tubules, because these insects already acquired the leafhopper characters associated with brochosome transport: long hind legs with rows of tibial macrosetae, narrow tegmina with $\mathrm{MP}+\mathrm{CuA} 1$ anastomosis, and reduced surface sculpture.

РЕЗЮМЕ. Новые монотипные роды из средней юры Южной Сибири (Kisa fasciata gen. et sp.n., Kubecola guttatus gen. et sp.n., Kemobius lux gen. et sp.n.) и Cicadellium Westwood, 1854 помещены в подсемейство Karajassinae stat.n. Cicadellium psocus Westwood, 1854 (= Cercopidium telesphorus Westwood, 1854, syn.n.) обозначен как типовой вид рода Cicadellium (второй вид, C. dipsas Westwood, 1854 перенесен в Psocoptera). Новый монотипный род из верхней юры Южной Монголии (Dellashara tega gen. et sp.n.) и четыре нижнемеловых рода отнесены к подсемейству Dellasharinae subfam.n. Оба подсемейства включены в семейство Archijassidae, по- мещаемое в надсемейство Membracoidea. Mesojassus Tillyard, 1916 и Triassojassus Tillyard, 1919 из верхнего триаса Австралии принадлежат к Archijassinae и представляют собой древнейшие находки этого надсемейства. Прослежена последовательность приобретения мембракоидных признаков. Обсуждается ранняя эволюция мембракоидов. Вероятно, Karajassinae наносили на свое тело брохосомы или подобные им продукты секреции мальпигиевых сосудов, поскольку уже приобрели признаки цикаделлид, связанные с переносом брохосом: длинные задние ноги с рядами макрохет на голенях, узкие передние крылья со слиянием $\mathrm{MP}+\mathrm{CuA1}$, ослабленную скульптуру.

\section{Introduction}

The superfamily Membracoidea, which comprises two extant hemipteran groups, megadiverse leafhoppers and treehoppers, is traced back in the fossil record to the Triassic. However, the classification of Mesozoic membracoids remains controversial.

Westwood [1854] described various Mesozoic insects collected by Rev. Peter Brodie in the Purbeck Beds of England (now dated Early Cretaceous), including homopteran tegmina, named Cercopidium signoretii and $C$. telesphorus, and one hindwing, named Cicadellium psocus. Westwood interpreted Cercopidi$u m$ as belonging to Cercopidae sensu Latreille, who united in this family frog-, leaf-, and treehoppers, and Cicadellium as belonging to Cercopidae Cicadellinae. Handlirsch [1906-1908] separated Cercopidium signoretii and C. telesphorus into the genus Homopterulum, left unplaced between Jassidae, Fulgoridae, and Cercopidae or Procercopidae.

Handlirsch [1906-1908, 1939] created Archijassus and several related genera in Jassidae from the Liassic of Dobbertin. Tillyard [1916, 1919] described Upper Triassic Mesojassus and Triassojassus in the same family. For these and several other Triassic genera, Evans 
[1956] established the family Chiliocyclidae, placed near Cicadellidae. Becker-Migdisova [1962] transferred most of these genera into the family Archijassidae, left unplaced (along with Hylicellidae) between Cicadellidea and Cercopidea.

Martynov [1927] described from the Upper Jurassic of Kazakhstan the genus Karajassus in Jassidae. Later the family Karajassidae was erected and interpreted as the most basal group of Membracoidea, whereas Archijassinae were included into Hylicellidae, and this latter and Chiliocyclidae were separated into the superfamily Hylicelloidea, considered ancestral to all three extant superfamilies of Cicadomorpha [Shcherbakov, 1992, 1996]. However, Ansorge [1996] retained Archijassidae (including Karajassus) in the Membracoidea.

Hamilton [1971] created the family Jascopidae for a peculiar nymph found in Canadian Upper Cretaceous amber and combining cercopid and cicadellid characters. The genus Myangadina from the Lower Cretaceous of Asia was described in Cicadellidae [Shcherbakov, 1986, 1988]; later this genus, Homopterulum and some others were united into an unnamed group nearly filling the gap between Karajassidae and typical Cicadellidae and deserving at least subfamily rank [Shcherbakov, 1992]. However, Hamilton [1990, 1992] assigned Homopterulum, Myangadina, and two Early Cretaceous genera from Brazil (all four based on adults) to Jascopidae.

Additional fossils and new data on living leafhoppers allow reconsideration of the systematic position of some Mesozoic membracoids. The vein nomenclature used herein is after Shcherbakov [1984, 1996, 2011]. The specimens having both part and counterpart are indicated with " \pm ". The material on the new taxa described below is deposited at the Borissiak Paleontological Institute, Russian Academy of Sciences (PIN). Photographs of these specimens were taken using a Leica M165C stereomicroscope and Leica DFC425 camera. Kubecola guttatus sp.n. was imaged without coating with a Tescan Vega XMU scanning electron microscope. The photograph of C. psocus was taken in the Sackler Biological Imaging $\mathrm{Lab}$ at the Natural History Museum, London (NHM) using a Leica M125 stereomicroscope, 1.6x adapter, and Canon EOS 550D camera.

\section{Taxonomy}

\section{Superfamily Membracoidea Rafinesque, 1815}

Family Archijassidae Becker-Migdisova, 1962

DIAGNOSIS. Tegmen: CP present; bSc reduced; 6-8 full-sized apical cells; 1-3 subapical cells (one or two rm, sometimes ir absent). Hindwing: 5-6 full-sized apical cells (RA long; MP connected or completely fused to $\mathrm{CuA} 1$ ); Pcu and $1 \mathrm{~A}$ close but not connected proximally.

COMPOSITION. Archijassinae Becker-Migdisova, 1962, Karajassinae Shcherbakov, 1992, stat.n., and Dellasharinae Shcherbakov, subfam.n. (keyed below).

COMPARISON. Other membracoids have tegmina with the maximum of 5 full-sized apical cells (or reticulate venation) and hindwings with the maximum of 4 full-sized apical cells (RA short; MP completely fused to CuA1).

\section{Key to subfamilies of Archijassidae (wings)}

1 Tegmen: costal space broad (especially proximally); CP rather long, nearly longitudinal; $\mathrm{MP}$ and $\mathrm{CuA} 1$ connected by crossvein $m c u$ or X-junction. Hindwing: MP and CuA1 connected by crossvein $m c u$ or fused for some distance .............................................. Archijassinae

- Tegmen: costal space narrow (sometimes widened distally); CP shorter, oblique

2 Tegmen: MP and CuA1 connected by crossvein or fused for some (usually short) distance. Hindwing: MP and $\mathrm{CuA} 1$ connected by crossvein ............................. Karajassinae

- Tegmen: MP and CuA1 fused for some (usually long) distance. Hindwing: MP and CuA1 completely fused .. Dellasharinae

Subfamily Archijassinae Becker-Migdisova, 1962

DIAGNOSIS. Tegmen: costal space broad; CP rather long; $\mathrm{R}$ and $\mathrm{M}$ leaving basal cell at one point; crossvein $\mathrm{mcu}$ (sometimes short) present or replaced with X-junction (not anastomosis); 7-8 full-sized apical cells; $1-3$ subapical cells (radiomedial one either open or closed with additional crossvein $\mathrm{rm}$; occasionally ir absent and radial cell merged with next apical cell). Hindwing: 6 full-sized apical cells (RA long; MP and $\mathrm{CuA} 1$ connected with crossvein $m c u$ or fused for some distance); posterior apical cell sublanceolate $(\mathrm{CuA} 1$ and $\mathrm{CuA} 2$ more or less converging distally).

COMPOSITION. Archijassus Handlirsch, 1906 (= Atitizon Handlirsch, 1939 = Eojassus Handlirsch, 1939 = Liojas sus Handlirsch, 1939 = Parajassus Bode, 1953 = Mesocica da Becker-Migdisova, 1962 = Cixiella Becker-Migdisova, 1962) [see Ansorge, 1996], Mesoledra Evans, 1956 (= Handlirschiana Metcalf et Wade, 1966, nomina nova pro Mesojassus Handlirsch, 1939 non Tillyard, 1916), and Ardela Ansorge, 1996 from Lower and Middle Jurassic of Eurasia, and Mesojassus Tillyard, 1916 and Triassojassus Tillyard, 1919 from Upper Triassic of Australia.

REMARKS. Based on the photographs published by Jell [2004], Mesojassus and Triassojassus are assigned herein to Archijassinae. The tegmina of $T$. proavitus and $M$. ipsviciensis are very similar in their size and structure, except for the latter being narrower apically, with crossvein $m c u$ replaced by Xjunction. These conclusions have to be verified by re-examination of the holotypes.

\section{Key to genera of Archijassinae (TEgmen)}

$1 \mathrm{dSc}$ more proximal (pterostigmal cell long). M 3-branched - dSc more distal, about level of claval apex (pterostigmal cell short) ................................................................. 3

2 Short crossvein $m c u$ present. Tegmen broadly rounded apically ............................................... Triassojassus

- Crossvein $\mathrm{mcu}$ replaced with X-junction. Tegmen narrowly rounded apically .................................. Mesojassus

3 Single $\mathrm{rm}$ distal to $\mathrm{M}$ fork. M usually 4-branched ...........

— Two $\mathrm{rm}$ (additional $\mathrm{rm}$ at M fork) ............................... 4

$4 \mathrm{R}$ fork much before additional $\mathrm{rm}$. ir basal to $\mathrm{im}$. M usually 4-branched .................................................. Ardela

- $\mathrm{R}$ fork just additional $\mathrm{rm}$. ir about level of im. M 3branched ........................................................ Mesoledra

Subfamily Karajassinae Shcherbakov, 1992, stat.n.

DIAGNOSIS. Tegmen: costal space narrow (at least basal1y); CP short; R and M leaving basal cell separately, at one point, or forming stalk beyond it; MP and $\mathrm{CuA} 1$ connected by crossvein $m c u$ or fused for some distance; 7 full-sized apical 
cells; 2 (occasionally 3 ) subapical cells (if radiomedial one closed with additional crossvein $\mathrm{rm}$, then ir usually absent and radial cell merged with next apical cell). Hindwing: 6 full-sized apical cells (RA long; free MP and CuA1 connected with crossvein $\mathrm{mcu}$ ); posterior apical cell lanceolate $(\mathrm{CuA} 1$ and $\mathrm{CuA} 2$ converging distally). Postclypeus large, inflated. Three close-set ocelli on crown. Antennal flagellum retaining primary segmentation. Hind coxae transverse, together occupying entire width of metathorax. Hind tibia with strong pecten at flared apex, macrosetae of outer row on prominent bases.

COMPOSITION. Type genus, Cicadellium Westwood, 1854, and three new genera (all keyed below) from Jurassic and Lower Cretaceous of Eurasia.

REMARKS. Sinojassus Zhang, 1985 and Gurvanina Shcherbakov, 1986 from the Lower Cretaceous of Asia, originally assigned to Karajassidae, belong outside Archijassidae as understood here.

\section{Key to genera of Karajassinae (tegmen)}

1 Two $\mathrm{rm}$ (additional $\mathrm{rm}$ at $\mathrm{M}$ fork). $\mathrm{R}$ fork just before additional $\mathrm{rm}$ and $\mathrm{M}$ fork. Crossvein $\mathrm{mcu}$ very short or replaced with short anastomosis. Clavus punctate, remaining tegmen (remigium) feebly punctate in costal space and along veins. Usually $\mathrm{R}$ and $\mathrm{M}$ forming stalk beyond basal cell, and ir absent Kisa gen.n.

- Single $\mathrm{rm}$ distal to $\mathrm{M}$ fork. $\mathrm{R}$ fork much before $\mathrm{M}$ fork 2

$2 \mathrm{R}$ and $\mathrm{M}$ forming stalk beyond basal cell; arculus long. Crossvein ir present; $m c u$ not replaced with anastomosis. Remigium feebly punctate in costal space and along veins Kubecola gen.n.

- $\mathrm{R}$ and $\mathrm{M}$ not forming such stalk. Remigium distinctly punctate at least in costal space and along veins ........ 3

3 Crossvein $m c u$ developed. Medial cell shorter than M branches beyond it. Costal space as wide as radial and medial spaces combined. Remigium punctate only in costal space and along veins. Crossvein ir present. $\mathrm{R}$ and $\mathrm{M}$ leaving basal cell at same point; arculus long ..... Kemobius gen.n.

- Crossvein $m c u$ replaced with anastomosis. Medial cell long and wide, larger than $\mathrm{CuA}$ fork, longer than $\mathrm{M}$ branches beyond it. Costal space narrower, as wide as radial space. Remigium more extensively punctate .... 4

4 Crossvein ir present. $\mathrm{MP}+\mathrm{CuA} 1$ about as long as $\mathrm{CuA} 1$ beyond it. $\mathrm{CuA}$ beyond arculus arched to $\mathrm{CuP}$ and then

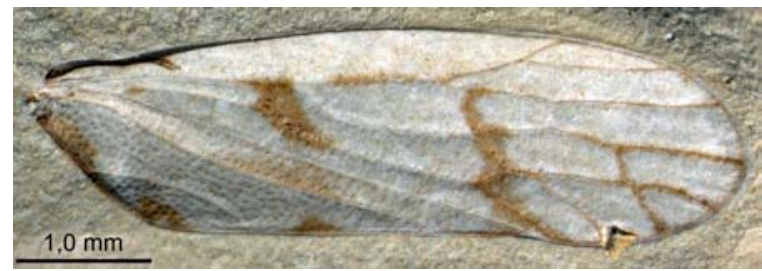

1

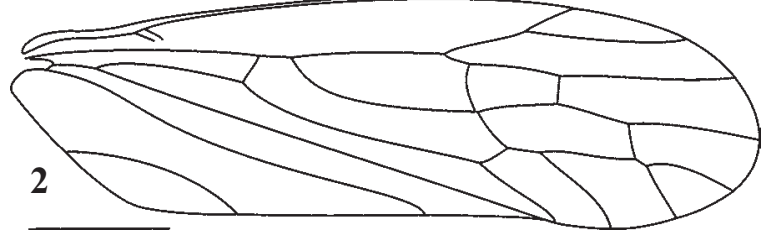

diverging from it. Tegmen very elongate (ca 3.7:1) ........

Cicadellium Westwood, 1854

- Crossvein ir absent. MP+CuA1 shorter than $\mathrm{CuA} 1$ beyond

it. $\mathrm{CuA}$ beyond arculus nearly parallel to $\mathrm{CuP}$. Tegmen

less elongate (2.6-3.0:1) . Karajassus Martynov, 1927

Kisa Shcherbakov, gen.n.

TYPE SPECIES. Kisa fasciata sp.n.

DIAGNOSIS. Tegmen: moderately elongate; costal space feebly punctate; two $r m$; $\mathrm{R}$ fork just before $\mathrm{M}$ fork; $\mathrm{R}+\mathrm{M}$ stalk usually present; arculus long; ir usually absent; medial cell large; $m c u$ very short or replaced with short anastomosis; claval veins arched towards each other.

COMPOSITION. Monobasic.

REMARKS. The largest tegmen assigned to the type species (1.7 times longer than the smallest one) lacks the $\mathrm{R}+\mathrm{M}$ stalk and retains a weak crossvein $i r$, but in the other venation features and distinctive dark pattern agrees with the remaining specimens. Presumably this species had a pronounced sexual dimorphism in size.

ETYMOLOGY. From acronym "Kubekovo, Itat Suite"; gender feminine.

\section{Kisa fasciata Shcherbakov, sp.n.}

MATERIAL. Holotype male(?) left tegmen PIN 1255/1562士; paratype tegmina 1255/429 (female?), $1563,1564 \pm, 1565 \pm$ (male?),

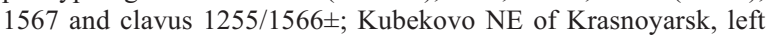
bank of Yenisei River; Itat Formation, Middle Jurassic.

DESCRIPTION (Figs 1-4). Tegmen 5.5-9.1 mm long and 1.6-2.7 mm wide, elongate (about 3.4:1), broadest beyond or at midlength, rounded at apex. Hypocostal carina narrow, precostal one even narrower; costal margin nearly straight proximally. Basal cell about 0.3 of tegmen length. Radial space at $\mathrm{R}$ fork narrower than costal space and about as wide as medial one. Normally $\mathrm{R}+\mathrm{M}$ stalk present and ir absent, but in largest specimen (PIN 1255/429) R+M stalk absent and weak ir present beyond midlength of pterostigmal cell. $\mathrm{rm}$ about midlength of medial cell. M stem continued with MA, medial cell more or less elongate. M branches beyond im shorter than medial cell, MP forked before or beyond im (sometimes MP2 with additional fork). $m c u$ usually developed and very short, as well as 1 st section of $\mathrm{CuA} 1$ (then two posterior apical cells very elongate and curved), but in smaller specimens often replaced with $\mathrm{X}$ -

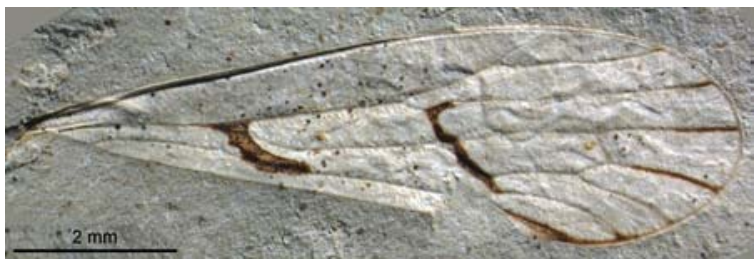

3

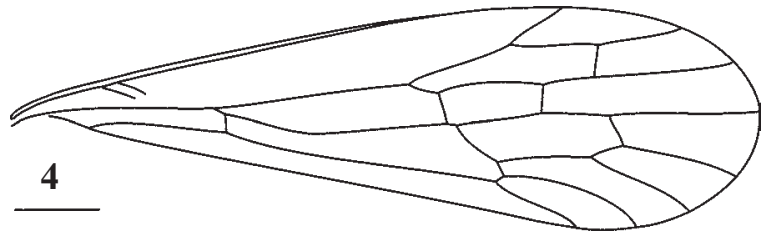

Figs 1-4. Kisa fasciata sp.n., Kubekovo, Middle Jurassic: 1-2 — holotype PIN 1255/1562, tegmen (1 - mirror image); 3-4 - paratype PIN 1255/429, tegmen.

Рис. 1-4. Kisa fasciata sp.n., Кубеково, средняя юра: 1-2 — голотип ПИН 1255/1562, переднее крыло (1 — перевёрнуто зеркально); 3-4 - паратип ПИН 1255/429, переднее крыло. 
junction (PIN 1255/1564) or short anastomosis (holotype), then 1st section of $\mathrm{CuA} 1$ longer. $\mathrm{CuA}$ stem not close to $\mathrm{CuP}$. Clavus rather densely, evenly, shallowly punctate, costal space sparsely and faintly so, the rest of remigium punctate only along veins. Tegmen pale with three transverse dark bands interrupted at least in costal space (at base along scutellar margin; at level of arculus; at nodal level), dark marking at $\mathrm{CP}$, and $\mathrm{M}$ and $\mathrm{CuA}$ branches darkened distally; clavus slightly suffused.

ETYMOLOGY. Latin fasciatus (banded).

Kubecola Shcherbakov, gen.n.

TYPE SPECIES. Kubecola guttatus sp.n.

DIAGNOSIS. Tegmen: moderately elongate; costal space feebly punctate; single $\mathrm{rm}$; $\mathrm{R}$ fork much before $\mathrm{M}$ fork; $\mathrm{R}+\mathrm{M}$ stalk present; arculus long; ir present; medial cell large; $\mathrm{mcu}$ short, not replaced with anastomosis; claval veins arched towards each other. Hindwing: rather broad; $m c u$ at $1 / 3$ of $\mathrm{CuA} 1 ; \mathrm{rm}$ more distal; $\mathrm{CuA}$ stem moderately curved; Pcu proximally well separated from $1 \mathrm{~A}$.

COMPOSITION. Monobasic.

REMARKS. All tegmina of Kubecola guttatus sp.n. are of similar size, suggesting that this species was less sexually dimorphic then Kisa fasciata sp.n.

COMPARISON. In the hindwing of Karajassus crassinervis Martynov, 1927, the crossvein $m c u$ is about the same level as $r m$, and Pcu proximally very close to $1 \mathrm{~A}$.

ETYMOLOGY. From Kubekovo and Latin - cola (dweller); gender masculine.

\section{Kubecola guttatus Shcherbakov, sp.n.}

MATERIAL. Holotype right tegmen and incomplete hindwing

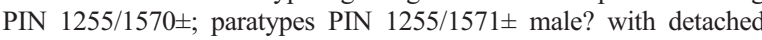
tegmen and hindwing, 1255/1572 \pm female with detached tegmen, and

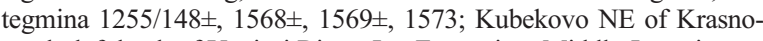
yarsk, left bank of Yenisei River; Itat Formation, Middle Jurassic.

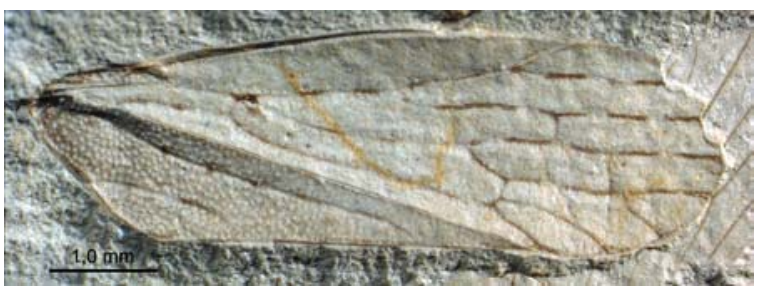

5

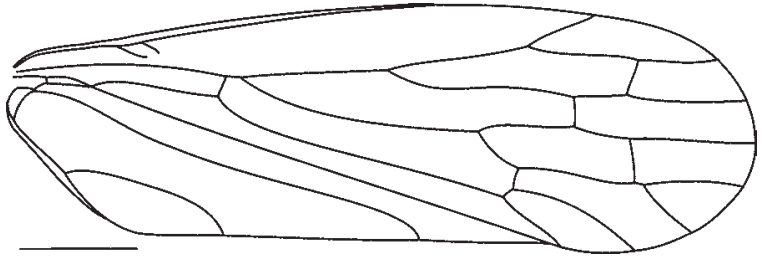

6

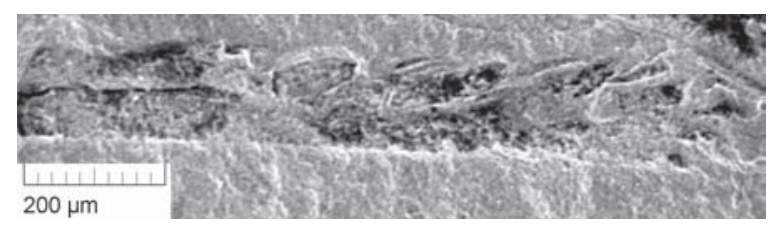

9
DESCRIPTION (Figs 5-9). Tegmen 6.4-7.5 mm long and 2.0-2.2 mm wide, elongate (ca 3.3:1), broadest beyond midlength, rounded at apex. Hypocostal carina narrow, precostal one even narrower; costal margin nearly straight proximally. Basal cell about 0.3 of tegmen length. $\mathrm{R}$ fork nearer to $M$ fork than to arculus, radial space at $R$ fork narrower than costal space and wider than medial one. ir beyond midlength of pterostigmal cell; $\mathrm{rm}$ at or beyond midlength of medial cell. M stem more or less continued with MA, medial cell more or less elongate. $\mathrm{M}$ branches beyond im shorter than medial cell, MP forked before or beyond im (sometimes MP2 with additional fork). $m c u$ short (usually as long as 1 st section of $\mathrm{CuA} 1$ ), sometimes very short. $\mathrm{CuA}$ stem not close to $\mathrm{CuP}$. Clavus rather densely punctate, more deeply towards base, costal space sparsely and faintly punctate, the rest of remigium punctate and transversely wrinkled only along veins. Tegmen pale; clavus suffused; veins dark with regular pale patches (much more extensive towards base); dark markings on vein tips near apical margin. Hindwing (PIN 1255/1571 with tegmen $7.5 \mathrm{~mm}$ long) $6.0 \mathrm{~mm}$ long, $3.2 \mathrm{~mm}$ wide, rather broad (1.9:1), apical cells moderately long. Costal margin with low triangular projection in basal $1 / 3$. Apical margin sinuate at $\mathrm{CuA} 2$. Basal cell wide, closed with arculus. $\mathrm{R}$ forked just before $1 / 2$ wing length; RA not much shorter than RP. $\mathrm{M}$ and $\mathrm{CuA}$ forked about 3/5 wing length, $\mathrm{M}$ slightly later; 1st section of MA sigmoidal, 1st section of MP straight. Crossvein $m c u$ at about $1 / 3 \mathrm{CuA} 1$ length, $r m$ more distal. RA and RP distally subparallel, MA and MP nearly so. $\mathrm{CuA} 1$ diverging from $\mathrm{MP}$ and converging to $\mathrm{CuA} 2$ from $m c u$ up to marginal sinus (apices of $\mathrm{CuA} 1$ and $\mathrm{CuA} 2$ close together); $\mathrm{CuA} 2$ arched against $m c u$. M stem gradually diverging from $\mathrm{R}$ up to fork. $\mathrm{CuA}$ stem nearly straight; $\mathrm{CuP}$ and Pcu moderately sigmoidal; Pcu proximally well sepa-

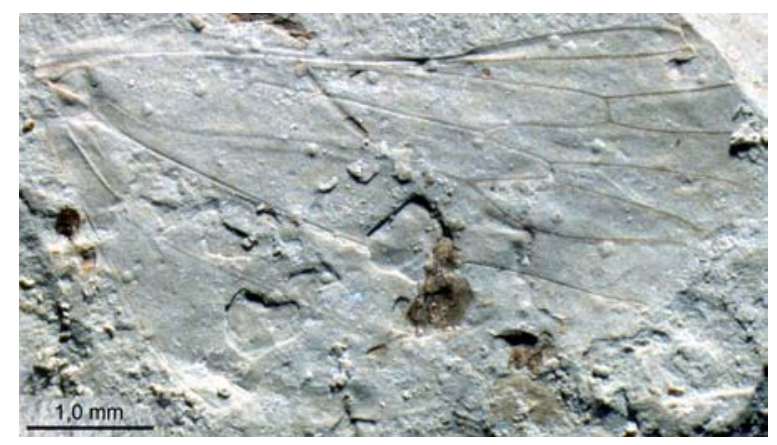

7

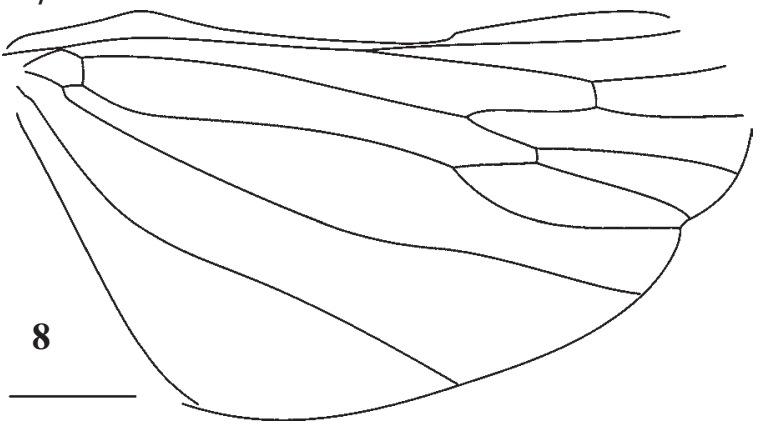

Figs 5-9. Kubecola guttatus sp.n., Kubekovo, Middle Jurassic: 5-6 - holotype PIN 1255/1570, tegmen (5 - mirror image of negative impression); 7-8 - paratype PIN 1255/1571, hindwing; 9 - paratype PIN 1255/1572, hind tibia, SEM micrograph.

Рис. 5-9. Kubecola guttatus sp.n., Кубеково, средняя юра: 5-6 — голотип ПИН 1255/1570, переднее крыло (5 - обратный отпечаток, перевёрнуто зеркально); 7-8 - паратип ПИН 1255/1571, заднее крыло; 9 - паратип ПИН 1255/1572, задняя голень, СЭМ микрофотография. 
rated from 1A. Body remains fragmentarily preserved. Hind tibia (PIN 1255/1571) with at least three longitudinal ribs; macrosetae of outer row relatively slender, nearly straight, about as long as tibia width, on prominent spine-like bases; these spines slightly inflated, bluntly pointed, set at about $30^{\circ}$ to tibia axis. Ovipositor (PIN 1255/1572) projecting beyond 9 th abdominal segment.

ETYMOLOGY. Latin guttatus (speckled).

\section{Kemobius Shcherbakov, gen.n.}

TYPE SPECIES. Kemobius lux sp.n.

DIAGNOSIS. Tegmen: rather broad; costal space wide, punctate; single $\mathrm{rm}$; $\mathrm{R}$ fork much before $\mathrm{M}$ fork; $\mathrm{R}$ and $\mathrm{M}$ leaving basal cell at one point; arculus long; ir present; medial cell short; $m c u$ not replaced with anastomosis.

COMPOSITION. Monobasic.

ETYMOLOGY. From Kem (Khakas name for upper reaches of the Yenisei River) and Greek bios (life); gender masculine.

\section{Kemobius lux Shcherbakov, sp.n.}

MATERIAL. Holotype left tegmen PIN 1255/1561 (without clavus); Kubekovo NE of Krasnoyarsk, left bank of Yenisei River; Itat Formation, Middle Jurassic.

DESCRIPTION (Figs 10-11). Tegmen $5.9 \mathrm{~mm}$ long and $2.0 \mathrm{~mm}$ wide, moderately elongate (ca 3.0:1), broadest beyond midlength, rounded at apex. Hypocostal carina rather wide; costal margin nearly straight proximally. Basal cell about 0.3 of tegmen length. $\mathrm{R}$ fork nearer to $\mathrm{M}$ fork than to arculus, radial space at $\mathrm{R}$ fork much narrower than costal space and as wide as medial one. ir about midlength of pterostigmal cell; $\mathrm{rm}$ beyond midlength of medial cell. M stem continued rather with MA, medial cell rather short. M branches beyond im longer than medial cell, MP forked just before im (MP1 with small additional fork). $m c u$ short, as long as 1 st section of $\mathrm{CuA} 1$. $\mathrm{CuA}$ stem not close to $\mathrm{CuP}$. Costal space sparsely, deeply punctate, the rest of remigium punctate only along veins. Tegmen suffused, more so on hypocostal carina and in middle of spaces and cells in posterior half of remigium; veins dark (especially proximally) with regular pale patches.

ETYMOLOGY. Latin lux (light).

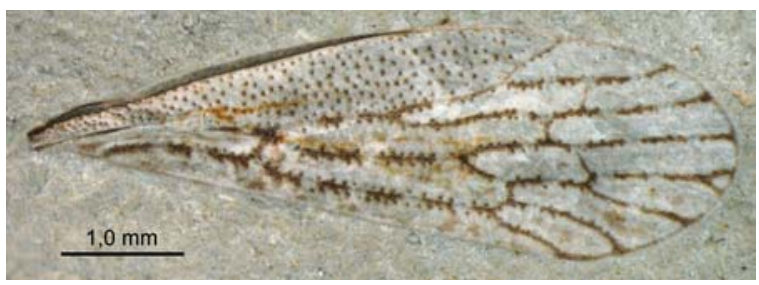

10

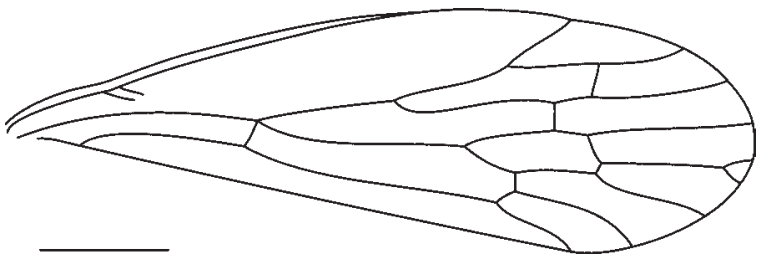

11

Figs 10-11. Kemobius lux sp.n., Kubekovo, Middle Jurassic, holotype PIN 1255/1561, tegmen.

Рис. 10-11. Kemobius lux sp.n., Кубеково, средняя юра, голотип ПИН 1255/1561, переднее крыло.
Cicadellium Westwood, 1854

Cicadellium: Westwood 1854: 393.

TYPE SPECIES. Cicadellium psocus Westwood, 1854

DIAGNOSIS. Tegmen: very elongate; proximal part punctate; single $r m$; R fork much before $\mathrm{M}$ fork; $\mathrm{R}$ and $\mathrm{M}$ leaving basal cell separately; arculus short; ir present; radial and medial cells long; $m c u$ replaced with rather long anastomosis; $\mathrm{CuA}$ beyond arculus arched and running close to $\mathrm{CuP}$; nodal line present. Hindwing: elongate; $m c u$ at $1 / 5$ of $\mathrm{CuA} 1 ; \mathrm{rm}$ more distal; $\mathrm{M}$ and $\mathrm{CuA}$ stems, $\mathrm{CuP}$ and Pcu markedly curved; Pcu proximally well separated from $1 \mathrm{~A}$.

COMPOSITION. Monobasic: Cicadellium psocus Westwood, $1854=$ Cercopidium telesphorus Westwood, 1854, syn.n.

COMPARISON. In the less elongated hindwings of Kubecola gen.n. and Karajassus the $\mathrm{M}$ and $\mathrm{CuA}$ stems, $\mathrm{CuP}$, and Pcu are less curved, and $m c u$ is at $1 / 3 \mathrm{CuA} 1$ length; in Karajassus also the crossvein $m c u$ is about the same level as $r m$, and Pcu proximally very close to $1 \mathrm{~A}$.

REMARKS. We designate here Cicadellium psocus Westwood, 1854 (based on the hindwing) as the type species of this genus. The second species originally assigned to the genus, C. dipsas Westwood, 1854 (based on the forewing), actually belongs in Psocoptera. There are diverse Karajassinae in the Purbeck Beds, but the C. psocus hindwing may be reliably associated with the Cercopidium telesphorus tegmen: both are collected by Rev. Peter Brodie from the same site and strata and agree in the size, the shape more elongated than in other genera, and some venation features (long distal forks, $\mathrm{MP}$ and $\mathrm{CuA}$ both arched backwards basally).

\section{Cicadellium psocus Westwood, 1854}

Cicadellium psocus: Westwood 1854: 394.

Cercopidium telesphorus: Westwood 1854: 394, syn.n.

Homopterulum telesphorus: Handlirsch 1906-8: 642.

MATERIAL. Holotype hindwing NHM I.11957 (nearly complete, costal margin poorly preserved); right tegmen (lacking base and clavus; holotype of Cercopidium telesphorus) on the slab NHM I.3968 (containing also holotypes of Pterinoblattina pluma (Giebel, 1856) and Pteromixanum purbeckianum (Handlirsch, 1906)); Brodie coll.; Durlston Bay, Swanage, Dorset, England; Middle Purbeck, Durlston Formation, Lowermost Cretaceous (Upper Berriasian).

DESCRIPTION (Figs 12-15). Tegmen $6.7 \mathrm{~mm}$ long and $1.8 \mathrm{~mm}$ wide (as preserved), very elongate (ca 3.7:1), broadest about midlength, acutely rounded at apex. Precostal carina very narrow (hypocostal one concealed in rock matrix); costal margin nearly straight proximally. Basal cell shorter than $1 / 3$ of tegmen. $\mathrm{R}$ fork about halfway between arculus and $\mathrm{M}$ fork, radial space at $\mathrm{R}$ fork wider than either costal or medial one. $\mathrm{M}$ stem subparallel to RA and RP. ir near apex of pterostigmal cell; $r m$ beyond midlength of medial cell. $\mathrm{M}$ fork rather symmetrical, medial cell elongate. $\mathrm{M}$ branches beyond im short, MP forked beyond $\mathrm{im}$. MP+CuAl about as long as $\mathrm{CuA} 1$ beyond it. $\mathrm{CuA}$ stem close to $\mathrm{CuP}$. Surface proximally rather deeply and densely punctate, especially in radial space, distally only along veins. Tegmen proximally darkened, with pale regular patches along costal margin, few spots on veins, and two large rounded spots at $\mathrm{M}$ stem (beyond arculus and before fork), distally slightly infuscate, veins near margin (especially $\mathrm{dSc}$ and $\mathrm{CuA}$ branches) and crossveins dark.

Hindwing $6.5 \mathrm{~mm}$ long, rather elongate (ca 2.3:1), apical cells very long. Apical margin sinuate at $\mathrm{CuA} 2$. Basal cell wide, closed with arculus. $\mathrm{R}$ forked just before $1 / 2$ wing length; RA not much shorter than RP. M and CuA forked about 5/8 wing length, $M$ somewhat earlier; 1 st section of MA straight, 1st section of MP arched backwards. Crossvein $m c u$ at about 1/5 CuA1 length, $r m$ more distal. MA and MP distally subparallel, RA and RP nearly so, all curved forwards. $\mathrm{CuA} 1$ diverging from $\mathrm{MP}$ and converging to $\mathrm{CuA} 2$ 


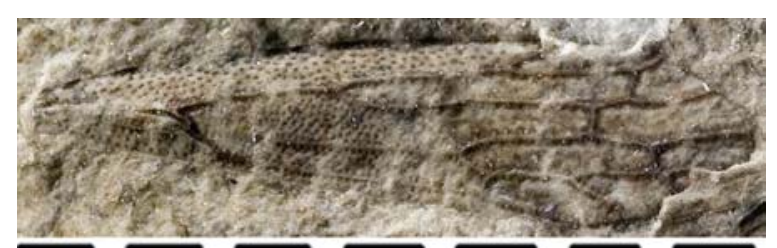

12

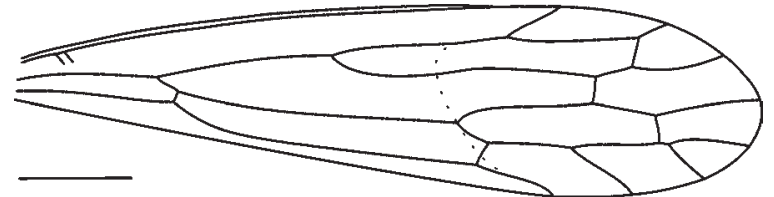

13

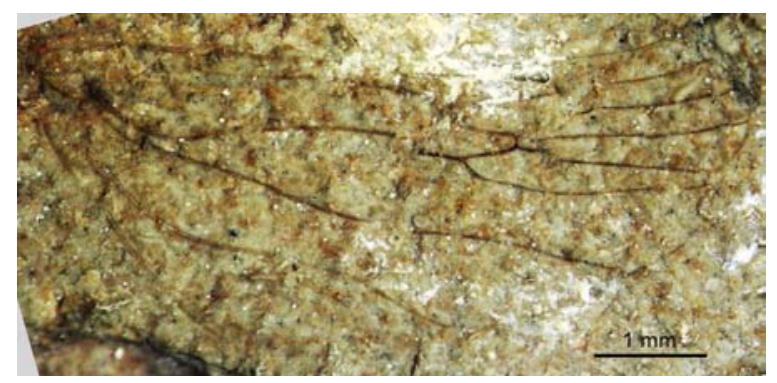

14

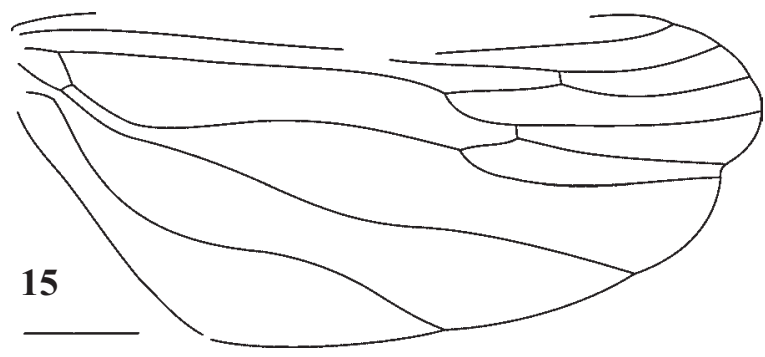

Figs 12-15. Cicadellium psocus Westwood, 1854, Durlston Bay, Lowermost Cretaceous: 12-13 — specimen NHM I.3968 (holotype of Cercopidium telesphorus Westwood, 1854), tegmen; 14-15 - holotype NHM I.11957, hindwing (14 - mirror image); 12,14 - (c) The Natural History Museum, London.

Pис. 12-15. Cicadellium psocus Westwood, 1854, Durlston Bay, базальный мел: 12-13 - экз. NHM I.3968 (голотип Cercopidium telesphorus Westwood, 1854), переднее крыло; 14-15голотип NHM I.11957, заднее крыло (14 - перевёрнуто зеркально); 12, 14 - (C) Музей естественной истории, Лондон.

from $m c u$ up to marginal sinus (apices of $\mathrm{CuA} 1$ and $\mathrm{CuA} 2$ nearly meet); $\mathrm{CuA} 2$ arched proximally, straight distally. $\mathrm{M}$ stem arched forwards distally, running close to R proximally. $\mathrm{CuA}$ stem deeply sigmoidal, arched close to $\mathrm{CuP}$ basally; CuP slightly wavy; Pcu moderately sigmoidal, proximally widely separated from $1 \mathrm{~A}$.

\section{Dellasharinae Shcherbakov, subfam.n.}

TYPE GENUS. Dellashara gen.n.

DIAGNOSIS. Tegmen: costal space narrow; CP short; R and $\mathrm{M}$ leaving basal cell separately; crossvein with anastomosis; 6-8 full-sized apical cells $(\mathrm{MP}+\mathrm{CuA} 1$ with 2-4 branches); 1-3 subapical cells (sometimes radiomedial one open and radial one merged with next apical cell). Hindwing: 5 full-sized apical cells (RA long; MP completely fused to $\mathrm{CuA} 1)$. Large inflated postclypeus extends onto crown. Three close-set ocelli on crown. Antennal flagellum setiform. Hind coxae transverse, together occupying entire width of metathorax. Hind tibia not flared at apex, with welldeveloped macrosetae lacking prominent bases.

COMPOSITION. Type genus from Upper Jurassic of Asia, and 4 genera from Lower Cretaceous of Eurasia: Acocephalites Meunier, 1904, Homopterulum Handlirsch, 1907, Mesoccus Zhang, 1985, and Myangadina Shcherbakov, 1986.

\section{Dellashara Shcherbakov, gen.n.}

TYPE SPECIES. Dellashara tega sp.n.

DIAGNOSIS. Tegmen: R fork distal; dSc moderately oblique; ir absent and $\mathrm{rm}$ single (one subapical cell); arculus short; $\mathrm{MP}+\mathrm{CuA} 1$ short; 6-7 apical cells. Hindwing: posterior apical cell (CuA fork) narrowed apically.

COMPARISON. In the other genera assigned, $\mathrm{R}$ fork more proximal (R stem subequal to 1st section of RA), dSc long and slanting, ir and at least weak additional $\mathrm{rm}$ at $\mathrm{M}$ fork present (three subapical cells), and MP+CuA1 longer in tegmen, and posterior apical cell not narrowed apically in hindwing.

COMPOSITION. Monobasic.

ETYMOLOGY. The genus and species are named from the genus Cicadella and Shar Teg; gender feminine.

\section{Dellashara tega sp.n.}

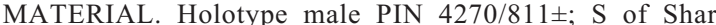
Teg mt, SW of Aj Bogd Uul range, SW Mongolia; Shar Teg Sequence, Upper Jurassic.

DESCRIPTION (Figs 16-18). Tegmen $5.3 \mathrm{~mm}$ long and $1.5 \mathrm{~mm}$ wide, quite elongate (ca 3.5:1), broadest about midlength, acutely rounded at apex. Precostal and hypocostal carinae very narrow; costal margin nearly straight proximally. Basal cell as long as 1/3 of tegmen. Arculus shorter than 1st section of $\mathrm{M}$ stem. $\mathrm{R}$ fork just before $\mathrm{M}$ fork, so that $\mathrm{R}$ stem ca. 4 times as long as 1 st section of RA (before dSc); radial space at $\mathrm{R}$ fork about as wide as costal space and wider than medial one. $\mathrm{rm}$ beyond midlength of medial cell. $\mathrm{M}$ fork rather symmetrical, medial cell elongate. $\mathrm{M}$ branches beyond im short, MP forked before $i m$. 6-7 apical cells (MP+CuA1 with 2 branches in left tegmen and 3 branches in right tegmen). $\mathrm{CuA}$ stem not close to $\mathrm{CuP}$. Clavus densely, shallowly punctate; remigium punctate mainly along veins and at base of costal space. Tegmen darkened, more so in costal space and especially in clavus. Hindwing $4.4 \mathrm{~mm}$ long and ca 2.0 $\mathrm{mm}$ wide, rather elongate (ca 2.2:1). Apical margin sinuate at $\mathrm{CuA} 2$. RA not much shorter than RP. M forked about $3 / 5$ wing length, $\mathrm{CuA}$ about $3 / 4$ wing length (just before $\mathrm{rm}$ ). 1 st section of MA sigmoidal, 1st section of MP straight. RA and $\mathrm{RP}$ distally subparallel, $\mathrm{MA}$ and $\mathrm{MP}+\mathrm{CuAl}$ nearly so; $\mathrm{MP}+\mathrm{CuA} 1$ and $\mathrm{CuA} 2$ diverging and then slightly converging. Posterior apical cell widest about midlength. M stem distally curved; CuA stem, $\mathrm{CuP}$ and Pcu moderately sigmoidal. Pcu proximally separated from 1A. Hindwing suffused. Body 7.4 $\mathrm{mm}$ long, dark (especially head, pronotum, and genitalia). Head ca $1.7 \mathrm{~mm}$ wide, in dorsal aspect with prominent eyes; crown transverse (ca 2.2:1) with anterior margin truncate, rounded towards eyes. Ocelli close-set, lateral ocelli separated by distance slightly greater than their diameter; median ocellus smaller than lateral ones. Pronotum ca $1.9 \mathrm{~mm}$ wide, $1.3 \mathrm{~mm}$ long, weakly transverse (ca $1.5: 1$ ), rounded hexagonal, covering mesonotum except for small apical portion $(0.3$ $\mathrm{mm}$ long). Head and pronotum densely punctate. Hind legs slender, not much elongated, tibia (1.8 $\mathrm{mm}$ long) 1.2 times as long as femur (1.5 mm long); tibia with at least three longitudinal ribs; macrosetae of outer row relatively strong, about as long as tibia width, without prominent spine-like bases; macrosetae of inner and ventral rows much shorter, dark.

\section{Discussion}

The family Karajassidae was characterized [Shcherbakov, 1992] as the most primitive membracoids, retaining 


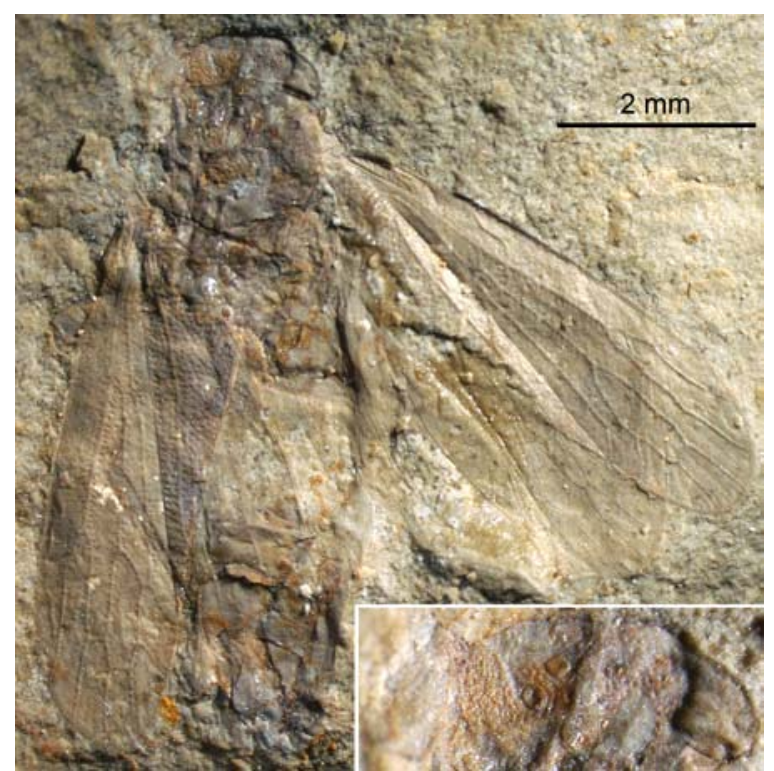

16 17

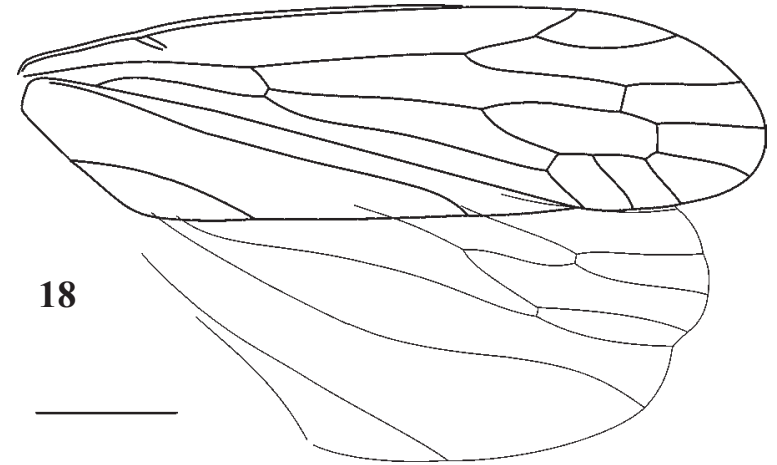

Figs 16-18. Dellashara tega sp.n., Shar Teg, Upper Jurassic, holotype PIN 4270/811, male: $16-$ habitus, $17-$ head in dorsal aspect; 18 - venation of right tegmen and hindwing.

Рис. 16-18. Dellashara tega sp.n., Шар Тэг, верхняя юра, голотип ПИН 4270/811, самец: 16 - общий вид, 17 - голова сверху; 18 - жилкование правого переднего и заднего крыльев.

the median ocellus, primary segmentation of the antennal flagellum, the CP in the tegmen, and the hindwing with six full-sized apical cells and Pcu not joined to 1A. The karajassid characters shared with leafhoppers were all interpreted as correlated to improvement of jumping abilities and constituting the key apomorphy of Membracoidea ("leafhopper syndrome"): (i) hind coxae transversely enlarged, together occupying entire width of metathorax; (ii) hind femora and tibiae long (knees not concealed by tegmina, gliding over their costal margins); (iii) macrosetal rows on tibiae; (iv) tibial and tarsal apical pectens narrow; (v) costal margin of tegmen straightened; (vi) tegmen and remigial part of hindwing narrowed, with $\mathrm{MP}+\mathrm{CuA} 1$ anastomosis. It was tacitly assumed that short-legged leafhoppers and treehoppers are not as good at jumping, and their hopping abilities have somewhat decreased secondarily.

Some facts on living membracoids cast doubt on this hypothesis. First, the long hind legs of leafhoppers with rows of tibial macrosetae are designed not only for jump- ing, but also (and perhaps more importantly) for distributing brochosomes over the body and tegmina through anointing and grooming behaviours. Brochosomes (microgranules produced in the Malpighian tubules) are found only in Cicadellidae; anointing behaviour is also observed in Membracidae [Rakitov, 1996, 1998, 2009, 2011].

Second, leafhoppers with shorter hind legs, like Ulopa, achieve similar take-off velocities and accelerate their bodies even more quickly than long-legged leafhoppers, such as Cicadella, but these latter have lower ground reaction forces and may jump better from less stiff substrates, such as leaves [Burrows \& Sutton, 2008]. Both long- and shortlegged ones are proficient hoppers, but the former are better in leaf-hopping, and the latter in stem- and treehopping (most treehoppers are short-legged).

Therefore, most if not all characters of the leafhopper syndrome (including (vii) surface sculpture of the body and tegmina reduced, and possibly (i) hind coxae differently shaped for more elaborate hind leg movements), can be interpreted as adaptations to manipulating brochosomes rather than to jumping, suggesting that Karajassinae already coated their integuments with these or related secretory particles.

Archijassinae, formerly placed in Cicadellidae or in or near Hylicellidae, remain insufficiently known; there are no data on their head and leg structure. They are undoubtedly ancestral to karajassines, being very similar in the fore and hind wing venation but showing none of the leafhopper syndrome characters, and therefore they were placed in Hylicelloidea as a subfamily of Hylicellidae [Shcherbakov, 1992]. The oldest, Middle Jurassic genera of Karajassinae described above nearly fill the gap between this group and Archijassinae, and this latter may be diagnosed only by the broader costal space with deeply arched costal margin in the tegmen. It seems reasonable to include both groups as subfamilies of the family Archijassidae within Membracoidea.

The Early Cretaceous genera assigned herein to Dellasharinae subfam.n. were previously mentioned as forming an unnamed group of at least subfamily rank, intermediate between karajassids and cicadellids. They were provisionally placed in Cicadellidae on account of the setiform antennal flagellum, three subapical cells in the tegmen, MP completely fused to $\mathrm{CuA} 1$ in the hindwing, and the long and stout tibial macrosetae. At the same time, these genera are more primitive than all living membracoids as indicated by the presence of five apical cells (due to long RA) and free Pcu and 1A in the hindwing [Shcherbakov, 1992]. The number of ocelli in these genera is still unknown.

The discovery of three close-set ocelli in Late Jurassic Dellashara gen.n. (the structure of the antennal flagellum in this genus is unknown) confirms that the Late Mesozoic membracoids with five apical cells in the hindwing were much more primitive than Cicadellidae and should be placed closer to Karajassinae. Dellashara gen.n. differs from the four Early Cretaceous genera (that resemble each other so closely that a revision is needed to confirm that some of them are not synonyms) in many tegminal characters, and no intermediates have been discovered so far. Despite this, we unite all five genera 
under one subfamily and imply that it is homogeneous in the head structure, because the difference between tegmina of the type genus and other dellasharines is of the same nature and magnitude as between e.g. Kisa gen.n. and Cicadellium, this latter gap bridged by other genera of Karajassinae. (If no such intermediates are eventually found for Dellasharinae, it may mean that this group is diphyletic and that Dellashara and the Early Cretaceous genera had acquired the hindwing MP fused to $\mathrm{CuA} 1$ independently.)

At present we include Archijassinae, Karajassinae, and Dellasharinae subfam.n., representing three successive stages of the early membracoid evolution, into one family Archijassidae. To elucidate the systematic position of Late Cretaceous Jascopus (based on a nymph) and Early Cretaceous Paracarsonini assigned to Jascopidae, further studies of Cretaceous Membracoidea are needed.

"Leafhopperization", i.e. successive acquisition of membracoid characters in the Archijassinae $\rightarrow$ Karajassinae $\rightarrow$ Dellasharinae $\rightarrow$ Cicadellidae lineage, was a long process spanning about a hundred million years. In the following list, these characters are arranged by the time of their first appearance in the fossil record:

- M with 3 branches (7 apical cells) in tegmen: Triassojassus - T3;

- arculus rather long in tegmen: Triassojassus - T3;

- Pcu and 1A proximally very close in hindwing: Archijassus etc. - J1;

- additional $\mathrm{rm}$ (3 subapical cells) in tegmen: Ardela, Mesole$d r a-\mathrm{J} 1$;

- short MP+CuA1 anastomosis in hindwing: Archijassus - J1;

- narrow costal space and straight costal margin in tegmen: Kubecola, Kisa - J2;

- reduced surface sculpture of tegmen: Kubecola, Kisa - J2;

- hind tibiae with rows of macrosetae, in outer row on spinelike bases: Kubecola - J2;

- hind coxae transversely enlarged: Karajassus - J3, presumably $\mathrm{J} 2$, possibly earlier;

- MP2 completely fused to CuA1 (6 apical cells) in tegmen: Dellashara - J3;

- MP completely fused to CuA1 (5 apical cells) in hindwing: Dellashara - J3.

- hind tibiae with rows of long and stout macrosetae: Dellashara - J3;

- antennal flagellum setiform: Myangadina, Mesoccus - K1, presumably $\mathrm{J} 3$;

- RA short (4 full-sized apical cells) in hindwing: Hallex etc. $-\mathrm{K} 1$;

- MP completely fused to CuA1 (5 apical cells) in tegmen: Hallex etc. - K1;

- Pcu and 1A fused for some distance in hindwing - K1;

- two ocelli: Hallex etc. - K1.

ACKNOWLEDGEMENTS. I am deeply indebted to Roman Rakitov (PIN) for valuable discussion, taking SEM micrographs, and checking the English of the manuscript, to Claire Mellish (NHM) for assistance with the NHM specimens, and to Phil Crabb and Vladimir Blagoderov (NHM) for photographing them.

\section{References}

Ansorge J. 1996. Insekten aus dem oberen Lias von Grimmen (Vorpommern, Norddeutschland) // Neue Paläontologische Abhandlungen. Vol.2. P.1-132.

Becker-Migdisova E.E. 1962. [Some new Hemiptera and Psocoptera] // Paleontologicheskiy Zhurnal. No.1. P.89-104 [in Russian].
Burrows M. \& Sutton G.P. 2008. The effect of leg length on jumping performance of short and long-legged leafhopper insects // Journal of Experimental Biology. Vol.211. P.13171325 .

Evans J.W. 1956. Palaeozoic and Mesozoic Hemiptera (Insecta) // Australian Journal of Zoology. Vol.4. P.165-258.

Hamilton K.G.A. 1971. A remarkable fossil homopteran from Canadian Cretaceous amber representing a new family // The Canadian Entomologist. Vol.103. P.943-946.

Hamilton K.G.A. 1990. Homoptera // D.A. Grimaldi (ed.). Insects from the Santana Formation, Lower Cretaceous, of Brazil. Bulletin of the American Museum of Natural History. Vol.195. P.82-122.

Hamilton K.G.A. 1992. Lower Cretaceous Homoptera from the Koonwarra Fossil Bed in Australia, with a new superfamily and synopsis of Mesozoic Homoptera // Annals of the Entomological Society of America. Vol.85. P.423-430.

Handlirsch A. 1906-1908. Die fossile Insekten und die Phylogenie der rezenten Formen. Leipzig: Wilhelm Engelmann. P. $1-1430$.

Handlirsch A. 1939. Neue Untersuchungen über die fossilen Insekten, part $1 / /$ Annalen des Naturhistorischen Museums in Wien. Vol.49. P.1-240.

Jell P.A. 2004. The fossil insects of Australia // Memoirs of the Queensland Museum. Vol.50. No.1. P.1-124.

Martynov A. 1927. Jurassic fossil insects from Turkestan. 6. Homoptera and Psocoptera // Bulletin de l'Académie des Sciences de l'URSS. 1926. Ser.6. Vol.20. No.13-14. P.13491366.

Rakitov R.A. 1996. Post-moulting behaviour associated with Malpighian tubule secretions in leafhoppers and treehoppers (Auchenorrhyncha: Membracoidea) // European Journal of Entomology. Vol.93. P.167-184.

Rakitov R.A. 1998. On differentiation of cicadellid leg chaetotaxy (Homoptera: Auchenorrhyncha: Membracoidea) // Russian Entomological Journal. Vol.6 (for 1997). No.3-4. P. 7-27.

Rakitov R.A. 2009. Brochosomal coatings of the integument of leafhoppers (Hemiptera, Cicadellidae) // S.N. Gorb (ed.). Functional Surfaces in Biology. Dordrecht etc.: Springer. Vol.1. P.113-137.

Rakitov R.A. 2011. Contamination as the cause of erroneous records of brochosomes // Psyche. Vol.2011. Article ID 767963. $4 \mathrm{pp}$.

Shcherbakov D.E. 1984. [System and phylogeny of Permian Cicadomorpha (Cimicida, Cicadina)] // Paleontologicheskiy Zhurnal. No.2. P.89-101 [in Russian; English translation: Paleontological Journal. 1984. Vol.18. No.2. P.87-97].

Shcherbakov D.E. 1986. [Homoptera. Cicadina (=Auchenorrhyncha)] // A.P. Rasnitsyn (ed.). Insects in the Early Cretaceous ecosystems of West Mongolia. Transactions of Joint Soviet-Mongolian Paleontological Expedition. Vol.28. P.47-50 [in Russian]

Shcherbakov D.E. 1988. [New Cicadina from the Late Mesozoic of Transbaikalia] // Paleontologicheskiy Zhurnal. No.4. P.55-66 [in Russian; English translation: Paleontological Journal. Vol.22. No.4. P.52-63].

Shcherbakov D.E. 1992. The earliest leafhoppers (Hemiptera: Karajassidae n. fam.) from the Jurassic of Karatau // Neues Jahrbuch für Geologie und Paläontologie Monatshefte. No.1. P.39-51

Shcherbakov D.E. 1996. Origin and evolution of the Auchenorrhyncha as shown by the fossil record // C.W. Schaefer (ed.). Studies on Hemipteran Phylogeny. Proceedings of Thomas Say Publications in Entomology. Entomological Society of America, Lanham, Maryland. P.31-45.

Shcherbakov D.E. 2011. New and little-known families of Hemiptera Cicadomorpha from the Triassic of Central Asia - early analogs of treehoppers and planthoppers // Zootaxa. No.2836. P.1-26

Tillyard R.J. 1916. Mesozoic and Tertiary insects of Queensland and New South Wales. Descriptions of the fossil insects // Queensland Geological Survey. Publication No.253. P.1160.

Tillyard R.J. 1919. Mesozoic insects of Queensland. No.7. Hemiptera Homoptera; with a note on the phylogeny of the suborder // Proceedings of the Linnean Society of New South Wales. Vol.44. P.857-896.

Westwood J.O. 1854. Contributions to fossil entomology // The Quarterly Journal of the Geological Society of London. Vol.10. P.378-396. 